\title{
Comparative Predictive Abilities of Earnings and Operating Cash Flows on Future Cash Flows: Empirical Evidence from Ghana
}

\author{
Joseph Akadeagre Agana ${ }^{1}$, Kwame Mireku $^{1} \&$ Kingsley Opoku Appiah ${ }^{1}$ \\ ${ }^{1}$ Department of Accounting and Finance, Kwame Nkrumah University of Science and Technology, Kumasi-Ghana \\ Correspondence: Joseph Akadeagre Agana, Department of Accounting and Finance, Kwame Nkrumah University of \\ Science and Technology, Kumasi-Ghana. E-mail: akadeagre4christ@gmail.com
}

Received: May 27, 2015

Accepted: June 22, 2015

Online Published: July 2, 2015

doi:10.5430/afr.v4n3p40

URL: http://dx.doi.org/10.5430/afr.v4n3p40

\begin{abstract}
Cash flow prediction is an essential component of economic decision making, particularly in investment and credit evaluation. This paper examines the comparative predictive ability of earnings and operating cash flows variables on future operating cash flows within a developing economy's setting. Ordinary Least Squares (OLS) method is used to develop regression models over the period of 2002 to 2012. Current operating cash flows, as proxy for future operating cash flows, are regressed on past one, two and three years of earnings and operating cash flows as predictors. Results from the regression analysis reveals earnings and operating cash flows are significant in predicting future operating cash flows but have different predictive powers with earnings providing a superior comparative predictive ability on future cash flows. The paper therefore concludes that earnings are a better predictor of future operating cash flows than historical operating cash flows itself.
\end{abstract}

Keywords: Comparative predictive ability, Earnings, Operating cash flows, Future cash flows

\section{Introduction}

Cash flow prediction is considered as an important task with respect to making economic decisions about an entity; decisions as to whether to invest in a particular firm or not is dependent on the investor's assertion of the entity's ability to generate cash flows in the future. Investors need information about future cash flows to predict the value of their investment. The ability of management to generate such future cash flow to both the advantage of the investors and the firm is reflected in its share price as reiterated by Narktabtee (2000) in his study on Thai stock market. Therefore it can be deduced that predicting future cash flows enables investors to predict share prices.

Several academics have attempted to examine the predictability of future operating cash flow using variables such as earnings, operating cash flows, accrual components of earnings and cash flow ratios. Cash flows from operations provide an essential indicator of the firm's ability to generate sustainable cash flows to repay and service liabilities, maintain operating activities, pay dividends to investors and provide internal source of financing for investments (IAS 7). Operating cash flows resulting from the principal activities of the firm has been used as an indicator of a firm's ability to meet other cash commitments (IAS 7). It is in this light that many studies have attempted predicting future operating cash flows using variables such as earnings, operating cash flows, accrual components of cash flows and cash flow ratios. Despite these, existing literature on the comparative predictive abilities of earnings and operating cash flows on future operating cash flows are inconsistent and inadequate. Some earlier studies (such as Finger, 1994; Charitou and Vafeas, 1998; Kim and Kross, 2005; Pae, 2005; Ebaid, 2011; Chong, 2012) reveal that historical earnings have more predictive power than operating cash flows. Others (Farshadfar, Ng and Brimble 2008;Penham and Yehuda, 2009; Habib, 2010; Waldron and Jordan, 2010) document that historical operating cash flows are superior to historical earnings in forecasting future operating cash flows. Yet, Arnold, Clubb, Manson and Wearing (1991), McBeth (1989), Pfeiffer, Elgers, Lo and Rees (1998) find no evident differences between these two types of accounting information in predicting future operating cash flows. Moreover, most of these studies are emanating from developed economies with few studies on emerging markets. For example Egypt (Ebaid, 2011), Indonesia (Supriyadi, 1998), Thailand (Chotkunakitti, 2005) and Malaysia (Chong, 2012).

Although, cash flow prediction is a useful tool in investment decision making, extant literature provides conflicting and inconclusive evidence on the relative predictive abilities of variables such as earnings and historical operating cash flows. Besides, the extant literature are mainly concentrated on developed economies. Developing economies 
such as those in Sub-Saharan African are left in a state of indecision considering the fact that extant literature is conflicting and inconclusive and especially that there are significant differences between these economies and those of Sub-Saharan Africa. It therefore stands to reason that a straightforward inference cannot be made for these emerging economies. This therefore calls for an investigation into the subject within the Sub-Saharan region taking into account the importance of the subject in the development of capital markets.

This study seeks to bridge the gap in literature and provide empirical evidence for investors in their investment decisions in the Sub-Saharan region.

The rest of the paper proceeds as follows. Brief review of related literature in Section 2, Section 3 presents the econometric estimation technique. Section 4 discusses the empirical results and concludes in Section 5.

\section{Literature Review}

Prior studies on the predictability of both earnings and operating cash flows on future operating cash flows are well documented (Barth, Cram and Nelson, 2001; Dechow, Kothari and Watts, 1998; Ebaid, 2011; Habib, 2010; Pae, 2005; Waldron and Jordan, 2010; Chotkunakitti 2005; Chong 2012). Yet, empirical findings are inconclusive on the comparative predictive abilities of earnings and operating cash flows on future operating cash flows. Some of these studies employed estimated cash flows from operating activities by adjusting net income before extraordinary items and discontinued operations for depreciation and amortization charges, changes in non-cash current assets and current liabilities as proxies for future operating cash flows (Gombola and Ketz, 1983; Greenberg, Johnson and Ramesh, 1986; Largay and Stickney, 1980). While Bowen, Burgstahler and Daley (1986); Greenberg et al. (1986); Largay and Stickney, (1980); Quirin, O'Bryan, Wilcox and Berry, (1999) use only operating activities excluding financing activities such as long term liabilities in their estimations, Gombola and Ketz (1983) however, utilize both operating and financing activities. These different estimation methods could also be a contributory factor to the conflicting findings emanating from the use of actual operating cash flows from the cash flow statement as against estimated operating cash flows. In line with the accounting standards setters, studies (Dechow et al., 1998; Ebaid, 2011; Greenberg et al., 1986; Kim and Kross, 2005; Murdoch and Krause, 1989 and 1990; Pae, 2005) conducted in the US confirm that historical earnings demonstrate higher predictive ability compared to historical operating cash flows. Contrarily, employing panel data from Australia, New Zealand and Thailand, Arthur, Czernkowski and Chen, (2007), Barth et al. (2001), Seng (2006) and Chotkunakitti (2005) reveal that historical operating cash flows predicts future operating cash flows better than historical earnings. However, Arnold et al. (1991), McBeth (1993), Pfeiffer et al. (1998) fail to find evidence using both methods of estimation using panel data from the UK and Germany.

\section{Methodology}

We use panel data from listed companies on the Ghana Stock Exchange (GSE) from 2002 to 2012. Listed firms without published financial statements within the period of analysis were removed from the analysis for consistency. Following Barth et al. (2001), Al-Altar and Hussain (2004), Chotkunakitti (2005), Habib (2010), Ebaid (2011), Chong (2012) we use Ordinary Least Squares to estimate the likely influence of the three-lags of operating cash flows and earnings ratios on future operating cash flows of the listed firms. The variables were scaled by the average total assets of the firms to eliminate the effects of size and heteroskedasticity problems (Anderson, Woodhouse, Ramsay and Faff, 2007; Hollister, Shoaf, and Tully 2008; Ebaid, 2011; Chong, 2012). The econometric regression model is of the form;

$$
\begin{aligned}
\mathrm{CFO}_{\mathrm{it}} & =\beta_{0}+\beta_{1} \mathrm{EARN}_{\mathrm{t}-1}+\varepsilon \\
\mathrm{CFO}_{\mathrm{it}} & =\beta_{0}+\beta_{1} \mathrm{EARN}_{\mathrm{t}-1}+\beta_{2} \mathrm{EARN}_{\mathrm{t}-2}+\varepsilon \\
\mathrm{CFO}_{\mathrm{it}}= & \beta_{0}+\beta_{1} \mathrm{EARN}_{\mathrm{t}-1}+\beta_{2} \mathrm{EARN}_{\mathrm{t}-2}+\beta_{3} \mathrm{EARN}_{\mathrm{t}-3}+\varepsilon \\
\mathrm{CFO}_{\mathrm{it}} & =\beta_{0}+\beta_{1} \mathrm{CFO}_{\mathrm{t}-1}+\varepsilon \\
\mathrm{CFO}_{\mathrm{it}} & =\beta_{0}+\beta_{1} \mathrm{CFO}_{\mathrm{t}-1}+\beta_{2} \mathrm{CFO}_{\mathrm{t}-2}+\varepsilon \\
\mathrm{CFO}_{\mathrm{it}} & =\beta_{0}+\beta_{1} \mathrm{CFO}_{\mathrm{t}-1}+\beta_{2} \mathrm{CFO}_{\mathrm{t}-2}+\beta_{3} \mathrm{CFO}_{\mathrm{t}-3}+\varepsilon
\end{aligned}
$$

Where $\mathrm{CFO}_{t}$ is the future operating cash flows for the year ${ }_{t}$ and ${ }_{i}$ is firm dimension, EARN and CFO are the earnings ratios and operating cash flows lagged up to three years, $\beta_{0}, \beta_{1}, \beta_{2}$ and $\beta_{3}$ are coefficients of the predictive variables and $\varepsilon$ represents the residual term. 


\section{Results and Discussion}

4.1 Correlation Analysis

Table 1. Descriptive Statistics and Correlation Matrix

\begin{tabular}{|c|c|c|c|c|c|c|c|c|c|c|}
\hline & Mean & SD. & 1 & 2 & 3 & 4 & 5 & 6 & 7 & 8 \\
\hline 1. CFO & 0.080 & 0.226 & 1.000 & & & & & & & \\
\hline 2. $\mathrm{CFO}_{\mathrm{t}-1}$ & 0.077 & 0.228 & $0.445^{* *}$ & 1.000 & & & & & & \\
\hline 3. $\mathrm{CFO}_{\mathrm{t}-2}$ & 0.073 & 0.235 & $0.278^{* *}$ & $0.448^{* *}$ & 1.000 & & & & & \\
\hline 4. $\mathrm{CFO}_{\mathrm{t}-3}$ & 0.073 & 0.240 & $0.333^{* *}$ & $0.272^{* *}$ & $0.432^{* *}$ & 1.000 & & & & \\
\hline 5. EARN & 0.043 & 0.181 & $0.432^{* *}$ & $0.399^{* *}$ & $0.308^{* *}$ & $0.315^{* *}$ & 1.000 & & & \\
\hline 6. EARN $_{\mathrm{t}-1}$ & 0.036 & 0.183 & $0.486^{* *}$ & $0.426^{* *}$ & $0.379^{* *}$ & $0.291^{* *}$ & $0.796^{* *}$ & 1.000 & & \\
\hline 7. EARN $_{\mathrm{t}-2}$ & 0.040 & 0.170 & $0.487^{* *}$ & $0.504^{* *}$ & $0.408^{* *}$ & $0.347^{* *}$ & $0.685^{* *}$ & $0.787^{* *}$ & 1.000 & \\
\hline 8. EARN $_{t-3}$ & 0.054 & 0.146 & $0.461^{* *}$ & $0.510^{* *}$ & $0.512^{* *}$ & $0.390^{* *}$ & $0.558^{* *}$ & $0.684^{* *}$ & $0.730^{* *}$ & 1.000 \\
\hline
\end{tabular}

**. Correlation is significant at the 0.01 level

Table 1 reports the absence of multicollinearity between the predictive variables as the magnitudes of the correlations were all less than 0.8 as recommended by Hair, Anderson, Tatham and Black (1998) and Field (2009) for presence of multicollinearity. We report significant and positive correlation between current operating cash flows $\left(\mathrm{CFO}_{t}\right)$ and the lags of operating cash flows $\left(\mathrm{CFO}_{\mathrm{t}-1}, \mathrm{CFO}_{\mathrm{t}-2}, \mathrm{CFO}_{\mathrm{t}-3}\right)$, as well as the lags of earnings $\left(\mathrm{EARN}_{\mathrm{t}-1}, \mathrm{EARN}_{\mathrm{t}-2}, \mathrm{EARN}_{\mathrm{t}-3}\right)$ at $5 \%$ significance level. This observation is consistent with those of Barth et al. (2001), Dechow et al. (1998), Chotkunakitti (2005) and Chong (2012).

\subsection{Regression Analysis}

Table 2. Summary of the regression of past earnings on future operating cash flows

\begin{tabular}{llll}
\hline Variables P values and coefficient & Adjusted $R^{2}$ & P values & $\begin{array}{l}\text { Significant Variables in each } \\
\text { Model }\end{array}$ \\
\hline EARN $_{t-1}(p=0.000$, coef $=.5142)$ & 0.2301 & $p<0.01$ & EARN $_{t-1}$ \\
EARN $_{t-1}(p=0.001$, coef $=.4108)$ & 0.2965 & $P<0.01$ & EARN $_{t-1}$ \\
$\operatorname{EARN~}_{t-2}(p=0.125$, coef $=.2261)$ & & & \\
EARN $_{t-1}(p=0.048$, coef $=.3171)$ & 0.3073 & $P<0.05$ & EARN $_{t-1}$ \\
$\operatorname{EARN~}_{t-2}(p=0.289$, coef $=.2114)$ & & & \\
$\operatorname{EARN~}_{t-3}(p=0.289$, coef $=.2172)$ & & & \\
\hline
\end{tabular}

\section{Source: Developed from Stata regression output}

Table 2 reports the summary of the Ordinary Least Squares regression analysis for the influence of past earnings on future operating cash flows for the listed firms. The results show that all the first lags of the three earnings models $\left(E A R N_{t-1}\right)$ are significant in predicting the variations in future operating cash flows $(C F O)$. These suggest that $1 \%$ change in past earnings causes about $51.42 \%, 41.08 \%$ and $31.71 \%$ changes in the future operating cash flows of the firms respectively. This significant positive relationship between earnings $\left(E A R N_{t-1}\right)$ and future operating cash flows $\left(C F O_{t}\right)$ confirms the validity of the findings of Accounting Standard Setters (IASB and FASB) and prior studies (Dechowet al., 1998; Barth et al., 2001; Al-Attarand Hussain, 2004; Kim and Kross, 2005;Hollister et al., 2008; Jordan, 2010; Ebaid, 2011; Chong, 2012), suggesting that accounts prepared on accrual basis resulting in earnings $\left(E A R N_{t-1}\right)$ are able to assist investors in predicting future cash flows of their investment over a one year horizon. However, we report insignificant positive relationship between past earnings and future operating cash flow of the listed firms for the second and third lags of past earnings. The r-squared values of $0.2301,0.2965$ and 0.3073 suggest that the past earnings lagged over the period of analysis can predict about $23.01,29.65$ and $30.73 \%$ of the future operating cash flows of the listed firms. 
Table 3. Summary of the regression of past operating cash flows on future operating cash flows

\begin{tabular}{|c|c|c|c|}
\hline Variables $P$ values and coefficient & Adjusted $R^{2}$ & Pvalue & Significant Variables in each Model \\
\hline $\mathrm{CFO}_{\mathrm{t}-1}(\mathrm{p}=0.000$, coef $=.3424)$ & 0.1910 & $\mathbf{P}<0.01$ & $\mathrm{CFO}_{\mathrm{t}-1}$ \\
\hline $\begin{array}{l}\mathrm{CFO}_{\mathrm{t}-1}(p=0.001, \operatorname{coef}=.3488) \\
\mathrm{CFO}_{\mathrm{t}-2}(p=0.214, \operatorname{coef}=.0907)\end{array}$ & 0.1574 & $\mathbf{P}<0.01$ & $\mathrm{CFO}_{\mathrm{t}-1}$ \\
\hline $\begin{array}{l}C F O_{t-1}(p=0.005, \text { coef }=.3133) \\
C F O_{t-2}(p=0.070, \text { coef }=.2031) \\
C F O_{t-3}(p=0.072, \text { coef }=.1205)\end{array}$ & 0.2264 & $\begin{array}{l}P<0.01 \\
P<0.1\end{array}$ & $\mathrm{CFO}_{\mathrm{t}-1}$ \\
\hline
\end{tabular}

Source: Developed from Stata Regression Output

Table 3 reports the summary of the Ordinary Least Squares regression analysis for the influence of past operating cash flows on future operating cash flows for the listed firms. The results show that all the one lags of the past operating cash flows $\left(\mathrm{CFO}_{t-1}\right)$ in all instances are significant in predicting the variations in future operating cash flows $(C F O)$ at $1 \%$ significance level. These suggest that $1 \%$ change in past operating cash flow causes about $34.24 \%, 34.88 \%$ and $31.33 \%$ changes in future operating cash flows of the firms respectively. However, we report significant positive relationship between the second lag $\left(\mathrm{CFO}_{t-2}\right)$ and third lag $\left(\mathrm{CFO}_{t-3}\right)$ of the past operating cash flows and future operating cash flow of the listed firms at $10 \%$ significance level. These significant positive relationship between the past operating cash flows and future operating cash flows confirms findings of prior studies (such as Stamerjohan and Nassiripour, 2001; Al-Attarand Hussain, 2004;Chotkunakitti, 2006; Chong, 2012) suggesting that operating cash flows has credibility in predicting future cash flows. The r-squared values of 0.1910, 0.1574 and 0.2264 suggest that past operating cash flows lagged over the three years horizons can predict about $19.10,15.74$ and $22.64 \%$ of the future operating cash flows of the listed firms.

\section{Conclusions and Directions for Future Research}

Using panel data, the study concludes that historical earnings and operating cash flows are significant in predicting future cash flows. It is however established that their predictive abilities differs and that historical earnings have superior predictive ability on future operating cash flows than historical operating cash flows. Operating cash flows therefore has the least predictive ability on future operating cash flows. It has also been established that investors who seek to predict future operating cash flows on their investments by relying on three years ago earnings, two years ago earnings and a year ago earnings would make some gains in terms of precision than those using just one year and only past operating cash flows as proxy for predicting their future operating cash flow in a developing economy such as Ghana.

Future studies can examine and compare the relative predictive abilities of disaggregated accruals and disaggregated operating cash flows components (such as operating cash flows from customers, suppliers etc.), investing or financing operating cash flows.

\section{References}

Al-Attar, A. \& Hussain, S. (2004). Corporate data and future cash flow. Journal of Business Finance and Accounting, 31(7-8), 861-903. http://dx.doi.org/10.1111/j.0306-686X.2004.00560.x

Anderson, K., Woodhouse, K., Ramsay, A. \& Faff, R. (2007). The persistence and pricing of earnings, accruals and free cash flows in Australia. Working Paper, Australian Accounting Standards Board and Monash University.

Arnold, A. J., Clubb, C. D. B., Manson, S. \& Wearing, R. T. (1991). The relationship between earnings, funds flows and cash flows: evidence for the UK. Accounting and Business Research, 22(85), 13-19. http://dx.doi.org/10.1080/00014788.1991.9729413

Arthur, N., Czernkowski, R. \& Chen, M. (2007). The persistence of cash flow components into future earnings. Working Paper, University of Sydney.

Barth, M. E., Cram, D. P. \& Nelson, K. K. (2001). Accruals and the prediction of future cash flows. The Accounting Review, 76(1), 27-58, 283. http://dx.doi.org/10.1108/01409171111146715

Bowen, R. M., Burgstahler, D. \& Daley, L. A. (1986). Evidence on the relationships between earnings and various measures of cash flow. The Accounting Review, 61(4), 713-25. 
Charitou, A. \& Vafeas, N. (1998). The association between operating cash flows and dividend changes: an empirical investigation. Journal of Business Finance and Accounting, 25(1-2), 225-249. http://dx.doi.org/10.1111/1468-5957.00185

Chong, K. W. (2012). Prediction of operating cash flows using accrual-based and cash-based accounting information among Malaysian industrial corporations.DBA thesis, Southern Cross University, Lismore, NSW.

Chotkunakitti, P. (2005). Cash flows and accrual accounting in predicting future cash flow of Thai listed companies. DBA thesis, Southern Cross University Lismore, NSW.

Dechow, P. M., Kothari, S. P. \& Watts, R. L. (1998). The relation between earnings and cash flows. Journal of Accounting and Economics, 25(2), 133-168. http://dx.doi.org/10.1016/S0165-4101(98)00020-2

Ebaid, I. E. (2011). Accruals and the prediction of future cash flows: empirical evidence from an emerging market. Management Research Review, 34(7), 1-32. 291. http://dx.doi.org/10.1108/01409171111146715

Farshadfar, S., Ng, C. \& Brimble, M. (2008). The relative ability of earnings and cash flow data in forecasting future cash flows. Pacific Accounting Review, 20(3), 251-268. http://dx.doi.org/10.1108/01140580810920236

Finger, C. A. (1994). The ability of earnings to predict future earnings and cash flow. Journal of Accounting Research, 32(2), 210-23. http://dx.doi.org/10.5539/ijbm.v9n2p235

Gombola, M. J. \& Ketz, J. E. (1983). A note on cash flow and classification patterns of financial ratios. The Accounting Review, 58(1), 105-14.

Greenberg, R. R., Johnson, G. L. \& Ramesh, K. (1986). Earnings versus cash flows as a predictor of future cash flow measures. Journal of Accounting Auditing and Finance, 1(4), 266-77.

Habib, A. (2010). Prediction of operating cash flows: further evidence from Australia. Australian Accounting Review, 20(2), 134. http://dx.doi.org/10.1111/j.1835-2561.2010.00086.x

Hair, J. F., Anderson, R. E.,Tatham, R. L. \& Black, W. C. (1998). Multivariate Data Analysis(5th edition), Prentice Hall, New Jersey.

Hollister, J., Shoaf, V. \& Tully, G. (2008). The effect of accounting regime characteristics on the prediction of future cash flows: an international comparison. International Business and Economics Research Journal, 7(5), 15-30.

Jordan, C. E., Waldron, A. \& Clark, S. J. (2007). An analysis of the comparative predictive abilities of operating cash flows, earnings and sales. The Journal of Applied Business Research, 23(3), 53-60.

Kim, M. \& Kross, W. (2005). The ability of earnings to predict future operating cash flows has been increasing - not decreasing. Journal of Accounting Research, $43(5), \quad 753 \quad-780$. http://dx.doi.org/10.1111/j.1475-679X.2005.00189.x

Largay, J. \& Stickney C. (1980). Cash flows, ratio analysis and the W.T. Grant Company bankruptcy. Financial Analysts Journal, 36(4), 51-54. http://dx.doi.org/10.2469/faj.v36.n4.51

McBeth, K. H. (1993). Forecasting operating cash flow: Evidence on the comparative predictive abilities of net income and operating cash flow from actual cash flow data. The Mid-Atlantic Journal of Business, 29(2), $173-87$.

Murdoch, B. \& Krause, P. (1989). An empirical investigation of the predictive power of accrual and cash flow data in forecasting operating cash flow. Akron Business and Economic Review, 20(3), 100-13. 301.

Murdoch, B. \& Krause, P. (1990). Further evidence on the comparative ability of accounting data to predict operating cash flows. The Mid - Atlantic Journal of Business, 26(2), 1-14.

Narktabtee, K. (2000). The implications of accounting information in the Thai capital market, PhD thesis, University of Arkansas, Thailand.

Pae J. (2005). Expected accrual models: the impact of operating cash flows and reversals of accruals. Review of Quantitative Finance and Accounting, 24(1), 5-22. http://dx.doi.org/10.2139/ssrn.599562

Penham, S. H. \& Yehuda, N. (2009). The pricing of earnings and cash flows and the affirmation of accrual accounting. Review of Accounting Studies, 14(4), 453-479. http://dx.doi.org/10.1007/s11142-009-9109-4

Pfeiffer, R. J., Elgers, P.T., Lo, M. H. \& L. L. Rees (1998). Additional evidence on the incremental information content of cash flows and accruals: the impact of errors in measuring market expectations. Accounting Review, 73(3), $373-385$. 
Quirin, J. J., O'Bryan, D., Wilcox, W. E. \& Berry, K. T. (1999). Forecasting cash flow from operations: additional evidence. The Mid - Atlantic Journal of Business, 35(2-3),135-42.

Seng, D. (2006). Earnings versus cash flows as predictors of future cash flows: New Zealand evidence. Working Paper, University of Otago.

Stammerjohan, W. W. \& Nassiripour, S. (2001). Predicting SFAS 95 cash flows: the relative importance of prior earnings, cash flows and accruals. Accounting Enquiries, 10(1), 87-146. http://dx.doi.org/10.6007/IJARAFMS/v3-i4/385.

Supriyadi. (1998). The association between accounting information and future cash flows: an Indonesian case study, $\mathrm{PhD}$ thesis, University of Kentucky.

Waldron, M. A. \& Jordan, C. E. (2010). The comparative predictive abilities of accrual earnings and cash flows in periods of economic turbulence: the case of the bubble. The Journal of Applied Business Research, 26(1), 85-97. http://arrow.unisa .edu.au: 8081/1959.8/100389. 